\title{
ДОСЛІДЖЕННЯ ЗМІН ГЕМАТОЛОГІЧНИХ ІНДЕКСІВ НА ТЛІ ГЕМАТОСУПРЕСІї, ВИКЛИКАНОЇ ДІЄЮ ЦИКЛОФОСФОАМІДУ
}

\section{Дослідження змін гематологічних індексів на тлі гематосупресії, викликаної дією циклофосфооаміду}

\section{С. О. Ястремська, Н. М. Петрик}

Тернопільський національний медичний університет імені І. Я. Горбачевського МОЗ України

Резюме. Гематосупресія, викликана дією цитостатичних препаратів, що відносяться до групи алкілуючих сполук, у гематології є частим явищем, із компенсацією даного стану за рахунок появи ділянок екстрамедулярного гемопоезу (ЕМГ) в перифрерійних органах кровотворення. Оцінка зміни гематологічних індексів, які виникають при ЕМГ, спрямована на розробку додаткових діагностичних критеріїв захворювань системи крові.

Мета дослідження - вивчити зміни гематологічних індексів периферійної крові при гематосупресії, викликаній циклосроссроамідом.

Матеріали і методи. Дослідження виконано на 30 статевозрілих мишах Balb/c із середньою масою тварин 25 г, яких поділили на дві групи, - інтактну і дослідну по 15 мишей у кожній. Для індукції ектрамедулярного гемопоезу використано мобілізаційний протокол, розроблений на кафедрі патології та біології розвитку Стенорордського університету [5]. Тваринам дослідної групи в перший день експеременту внутрішньочеревно вводили болюсну дозу циклофроссроаміду («Ендоксан», виробник «Baxter Oncology GmbH» (Німеччина)) - 200 мг/ке із наступними триденними внутрішньочеревними ін'єкціями людського рекомбінантного гранулоцитарного колонієстимулювального фактора G-CSF (препарат «Грастим» виробник Dr. Reddy's (Індія)) в дозуванні 250 мкг/ке. Оцінку гематосупресії, викликаної комбінацією циклофросфроаміду та G-CSF, виконували у віддалений період на 21 добу експерименту. Для дослідження було відібрано цільну кров, забір якої здійснено 3 порожнини серця. Дослідження гематологічних індексів проведено на аналізаторі Horiba Yumizen $\mathrm{H}_{500}$.

Результати. Виявлено повну компенсацію анемічних проявів, викликаних гематосупресією на 21 добу експерименту, на що вказує достовірне $(p<0,025)$ збільшення абсолютної кількості еритроцитів на 119,34 \%, із збереженням морфометричних параметрів у межах норми в новій популяції еритроцитів та незначним збільшенням їх гетерогенності, виявленого на основі достовірного $(p<0,001)$ підвищення коефріцієнта варіації у дослідній групі на 16,12 \% та стандартного відхилення на 8,72 \%. Встановлено зміну тромбоцитарного (с). О. Ястремська, Н. М. Петрик, 2020

ISSN 2706-6282(print) ISSN 2706-6290(online)
Вісник медичних і біологічних досліджень Bulletin of Medical and Biological Research
Study of changes in hematological indices against the background of hematosuppression caused by cyclophosphamide

\section{S. O. Yastremskaya, N. M. Petryk}

I. Horbachevsky Ternopil National Medical University

e-mail: yastremska@tdmu.edu.ua

Summary. Hematosuppression caused by the action of cytostatic drugs belonging to the group of alkylating compounds in hematology is a common phenomenon, with compensation for this condition due to the appearance of areas of extramedullary hematopoiesis (EMH) in peripheral hematopoietic organs. Assessment of changes in hematological indices that occur during EMH is aimed at developing additional diagnostic criteria for diseases of the blood system.

The aim of the study - to investigate changes in peripheral blood hematological indices in cyclophosphamideinduced hematosuppression.

Materials and Methods. The study was performed on 30 adult mature Balb/c mice with an average weight of $25 \mathrm{~g}$ with a division into two groups of intact and experimental 15 mice in each. For the induction of extramedullary hematopoiesis, a mobilization protocol developed by the Department of Pathology and Developmental Biology of Stanford University was used [5]. Animals of the experimental group on the first day of the experiment were injected intraperitoneally with a bolus dose of cyclophosphamide ("Endoxan" manufactured by "Baxter Oncology GmbH" (Germany)) - 200 mg/kg, followed by three days of intraperitoneal injections of human recombinant granulocyte-colony manufacturer Dr. Reddy's (India)) in a dosage of $250 \mathrm{mcg} / \mathrm{kg}$.

Evaluation of hematosuppression caused by the combination of cyclophosphamide and G-CSF was performed remotely on day 21 of the experiment. Whole blood for the study taken from the heart cavity. The study of hematological indices was performed on a Horiba Yumizen H500 analyzer.

Results. Full compensation of anemic manifestations caused by hematosuppression on the 21st day of the experiment was revealed, which indicates a significant $(p<0.001)$ increase in the absolute number of erythrocytes by $119.34 \%$, with preservation of morphometric parameters within normal limits in a new population of erythrocytes and a slight increase in their heterogeneity. In the experimental group coefficient of variation by $16.12 \%(p<0.001)$ and the standard deviation by $8.72 \%$. The change in platelet homeostasis consisted in forming an excessive amount of 
гомеостазу, що полягала в утворенні надмірної кількості фрракції великих тромбоцитів у дослідній групі тварин на 52,23 \% (p<0,001) порівняно з показниками інтактної групи тварин. Відмічено незначне зменшення середнього об'єму тромбоцитів на 7,57 \% ( $p<0,001)$. Імуносупресія, викликана циклофоосфоамідом, що призводить до виникнення гострих форми нейтропенії на 21 добу експерименту, була повністю компенсована, про що свідчить збільшення абсолютного числа нейтрофрілів у 14,5 раза в дослідній групі тварин. Серед мієлоїдних клітин лейкоцитарного ряду спостерігається збільшення лімфоочитів, моноцитів, еозинофрілів та базофілів на 60,32; 66,99; 68,75; 76,39 \% відповідно.

Висновки. На основі змін гематологічних індексів периферійної крові ми виявили посилення гематопоезу клітин мієлоїдної та мегакаріацитарної ланки із компенсацією гематосупресії, викликаної ииклофоосороамідом на 21 добу експерименту. В тварин дослідної групи діагностовано посилення еритропоезу із компенсацією анемічних проявів, активацію тромбоцитарного гемопоезу та подоланням імуносупресії, викликаної дією циклофросфооміду за рахунок ін'єкцій G-CSF, що підтверджено збільшенням нейтрофрілій у 14,5 раза.

Ключові слова: гематосупресія; циклофосороамід; гематологічні індекси; екстрамедулярний гемопоез.

\section{ВСТУП}

Упродовж останнього десятиліття завдяки дослідженням вітчизняних та зарубіжних вчених у галузі експериментальної гематології вивчено етіологію та механізм виникнення екстрамедулярного гемопоезу (ЕМГ), розкрито клітинну нішу та ідентифріковано фрактори проліферації прогеніторних та гемопоетичних клітин-попередників. У клінічній практиці гематологи розглядають ЕМг як компенсаторну реакцію на недостатнє утворення або функціонування клітин крові, що зустрічається при вродженій гемолітичній анемії, при набутих захворюваннях кісткового мозку, зокрема при мієлодиспластичних синдромах. В окремих випадках ЕМГ індукується конститутивною надекспресією інтерлейкіну або кліщовою інвазією. Проте достеменно невідомо як координуються між собою процеси медулярного та екстрамедулярного кровотворення, якими властивостями володіють мобілізовані із кісткового мозку гемопоетичні попередники та прогеніторні клітини, а поліетіологічність та різна органна локалізація ЕМГ ускладнює встановлення причинно-наслідкових зв'язків та розуміння механізму його виникнення [4].

Нещодавні дослідження підтвердили, що анемічні прояви, викликані супресією кісткового мозку цитостатичними препаратами, які відносяться до групи алкілуючих сполук, швидше компенсовуються у тварин із збереженою селезінкою. Послаблення наслідків гематосупресії пов'язане із виникненням осередків екстрамедулярного кровотворення (ЕМГ) за рахунок появи прогеніторних гемопоетич- large platelet fraction in the experimental group of animals by $52.23 \%(p<0.001)$ compared with the intact group of animals. There was a slight decrease in mean platelet volume of $7.57 \%(p<0.001)$. Immunosuppression caused by cyclophosphamide leading to acute forms of neutropenia on day 21 of the experiment was fully compensated, as evidenced by an increase in the absolute number of neutrophils in 14.5 times the experimental group of animals. Among myeloid cells of the leukocyte lineage, there is increase in lymphocytes, monocytes, eosinophils and basophils by $60.32 \%, 66.99 \% 68.75 \%$ and $76.39 \%$ respectively.

Conclusions. Based on changes in hematological indices of peripheral blood, we found an increase in hematopoiesis of myeloid and megakaryocyte cells with compensation for hematosuppression caused by cyclophosphamide on day 21 of the experiment. In animals of the experimental group, increased erythropoiesis with compensation of anemic manifestations, activation of platelet hematopoiesis, and overcoming immunosuppression caused by cyclophosphamide G-CSF injections was confirmed, which was confirmed by a 14.5-fold increase in NEU.

Key words: hematosuppression; cyclophosphamide; hematological indices; extramedullary hematopoiesis.

них клітин у перифрерійних органах кровотворення, що в кінцевому результаті веде до збільшення целюлярності органа, а у випадку селезінки - до спленомегалії [11].

Станом на сьогодні серед науковців відсутня єдина точка зору стосовно характеру змін морфофункціональних показників формених елементів у динаміці перебігу мієлопроліферативних новоутворень (МПН), а наявні дані носять неоднозначний та суперечливий характер [2]. Враховуючи той оракт, що у здорових осіб розмір тромбоцитів (MPV) та їх кількість у периферійній крові $€$ генетично детермінованими показниками і кореляційний зв'язок між експресією генів та значенням параметра MPV було доведено, ми можемо стверджувати про діагностичну цінність даного параметра при різних патологічних станах і, зокрема, захворюваннях системи крові [1]. Так, дослідники усього світу активно вивчають можливість використання показників розмірів тромбоцитів для діагностики захворювань системи крові та оцінки стану цих клітин, що доводить перспективність досліджень у цьому напрямку [13]. Враховуючи вищесказане, ми констатуємо необхідність проведення додаткових досліджень для встановлення змін морфологічних особливостей фрормених елементів у хворих на МПН з метою розробки додаткових діагностичних критеріїв.

Метою дослідження було вивчити зміни гематологічних індексів периферійної крові при гематосупресії, викликаній циклофоосфоамідом. 


\section{МАТЕРІАЛИ I МЕТОДИ}

Для індукції ектрамедулярного гемопоезу використано мобілізаційний протокол, розроблений на кафредрі патології та біології розвитку Стенфордського університету [5]. В якості мобілізуючого агента використано препарат «Ендоксан» із діючою речовиною циклофоссроамід («Baxter Oncology $\mathrm{GmbH»} \mathrm{(Німеччина)).} \mathrm{Для} \mathrm{уникнення} \mathrm{тяжкої} \mathrm{форми}$ нейтропенії дослідним тваринам вводили ін'єкції людського рекомбінантного гранулоцитарного колонієстимулювального фрактора (G-CSF) («Грастим» Dr. Reddy's (Індія)). Комбінація циклофросфроаміду, який належить до групи алкілуючих агентів, та грастиму, що відноситься до групи колонієстимулювальних фракторів, базується на ідентичній реакції щодо середовища кісткового мозку, яка полягає у вивільненні та накопиченні нейтрофрільних протеаз, які забезпечуюють вихід стовбурових та прогеніторних клітин у периферійну кров [4].

Дослідження виконано на 30 статевозрілих мишах Balb/c із середньою масою тварин 25 г, яких поділили на дві групи: інтактну і дослідну із кількістю по 15 мишей у кожній. Тварин інтактної групи утримували в стандартних умовах віварію із збалансованим режимом харчування та дотриманням режиму світло/темрява. Тваринам дослідної групи в перший день експеременту внутрішньочеревно вводили болюсну дозу циклофоосфоаміду 200 мг/кг, що в перерахунку на середню масу тварин (25 г) відповідало 5 мг. Наступніі три дні тварини отримували внутрішньочеревні ін'єкції G-CSF у дозуванні 250 мкг/кг, що в перерахунку на масу миші відповідало 6,25 мкг.

Оцінку гематосупресії, викликаної комбінацією циклофоссроаміду та G-CSF, виконували у віддалений період на 21 день експерименту. Для дослідження було відібрано цільну кров, забір якої здійснено 3 порожнини серця. Дослідження гематологічних індексів проведено на аналізаторі Horiba Yumizen $\mathrm{H}_{500}$ із встановленням величини наступних параметрів: абсолютна кількість еритроцитів (RBC); гемоглобін (HGB); гематокрит (HCT); середній об'єм еритроцитів MCV; середній вміст гемоглобіну в еритроциті (MCH); середня концентрація гемоглобіну в еритроциті (MCHC); коефіцієнт варіації (RDW-CV); стандартне відхилення (RDW-SD); абсолютна кількість тромбоцитів (PLT); тромбокрит (РСТ); середній об'єм тромбоцита (MPV); ширина розподілу тромбоцита за об'ємом (PDW); кількість великих тромбоцитів (P-LCC); від- носний об'єм великих тромбоцитів (P-LCR); лейкоцити (WBC); нейтрофріли (NEU); лімфоцити (LYM); моноцити (MON); еозинофріли (EOS); базофіли (BAS); великі молоді клітини (LIC).

Статистичну обробку даних здійснювали за допомогою програмного забезпечення Exel (Microsoft, США), методом варіаційної статистики, статистично достовірними вважали зміни при р<0,05.

\section{РЕЗУЛЬТАТИ Й ОБГОВОРЕННЯ}

Аналіз змін еритроцитарних індексів на 21 добу експерименту свідчили про відсутність анемічних проявів, які викликані дією циклофосфоаміду. Так, у дослідній групі тварин спостерігалось посилення еритропоезу, встановлене на основі достовірного $(p<0,001)$ збільшення абсолютного числа еритроцитів на 119,34 \% та гемоглобіну $(p<0,001)$ на 113,49 \% порівняно 3 показниками інтактної групи тварин (табл. 1, рис. 1).

Варто зазначити, що новоутворені еритроцити в дослідній групі тварин зберігають морфофункціональні параметри у межах норми, на що вказують незначні зміни MCV, MCH, MCHC. У тварин дослідної групи спостерігалось незначне достовірне зменшення $(p<0,001)$ MCV та $(p<0,001) \mathrm{MCH}$ на $1,39$ та 3,18 \% та достовірне ( $p<0,001)$ збільшення MCHC на 1,52 \% порівняно 3 показниками інтактної групи тварин.

У віддалений період дії цитостатичного препарату ми виявили незначне збільшення гетерогенності популяції еритроцитів на основі зміни індексів анізоцитозу, а саме, RDW-CV та RDW-SD. Так, відсотковий розподіл еритроцитів за величиною RDW-CV достовірно ( $p<0,001)$ збільшився на 16,12 \%, а стандартне відхилення (різниця між найбільшим та найменшим діаметром еритроцитів) RDW-SD на 8,72 \% порівняно $з$ інтактною групою тварин (рис. 2).

Оцінка клітин мегакаріоцитарної ланки дозволяє стверджувати, що гематосупресія, спричинена болюсною дозою циклофосфоаміду, та триденні послідовні ін'єкції G-CSF, спрямовані на компенсацію імуносупресії та подолання нейтропенії, не викликала пригнічення гематопоезу клітин даної ланки, про що свідчить збільшення таких параметрів, як PLT, PCT, P-LCC та P-LCR (табл. 2). Так, у тварин дослідної групи виявлено достовірне ( $<<0,001)$ збільшення тромбокриту на $62,34 \%$, а загальна кількість тромбоцитів зросла на 61,87 \% порівняно $з$ показниками інтактної групи. Таким чином, ми констатуємо зміну тромбоцитарного гомеостазу за

Таблиця 1. Вплив циклофоссроаміду на еритроцитарні індекси периферійної крові мишей Balb/c

\begin{tabular}{l|c|c|c|c}
\hline \multicolumn{1}{c|}{ Параметр } & HGB, г/л & HCT, л/л & MCV, фрл & MCHC, г/л \\
\hline Інтактна група & $84,5 \pm 9,39$ & $0,469 \pm 0,18$ & $49,875 \pm 2,37$ & $302,0 \pm 2,14$ \\
\hline Дослідна група & $180,4 \pm 18,04$ & $0,279 \pm 0,012$ & $49,18 \pm 1,89$ & $297,4 \pm 2,94$ \\
\hline
\end{tabular}

Примітка. p<0,001, вірогідність відмінностей НGB, НCT, MCV, МСНС між контрольною і дослідними групами.

ISSN 2706-6282(print)

ISSN 2706-6290(online)
Вісник медичних і біологічних досліджень Bulletin of Medical and Biological Research
$4(6), 2020$ 


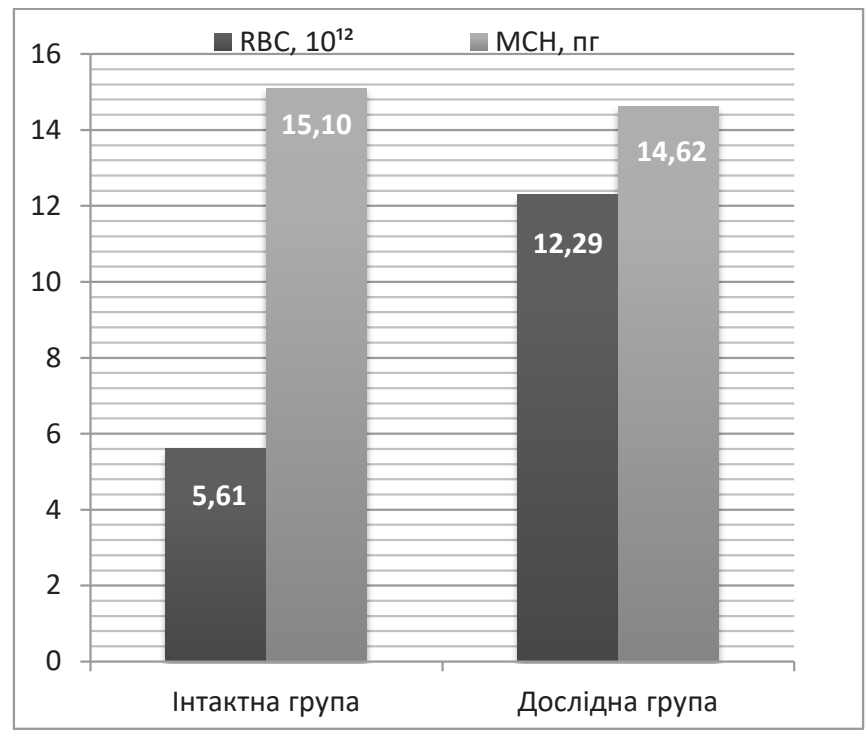

Рис. 1. Вплив циклофоосфоаміду на абсолютну кількість еритроцитів та середній вміст гемоглобіну в еритроциті перифрерійної крові мишей Ваlb/с.

Примітка. * - p<0,001, зміни RBC достовірні відносно показників інтактних тварин; p<0,001, зміни МСН достовірні відносно показників інтактних тварин.

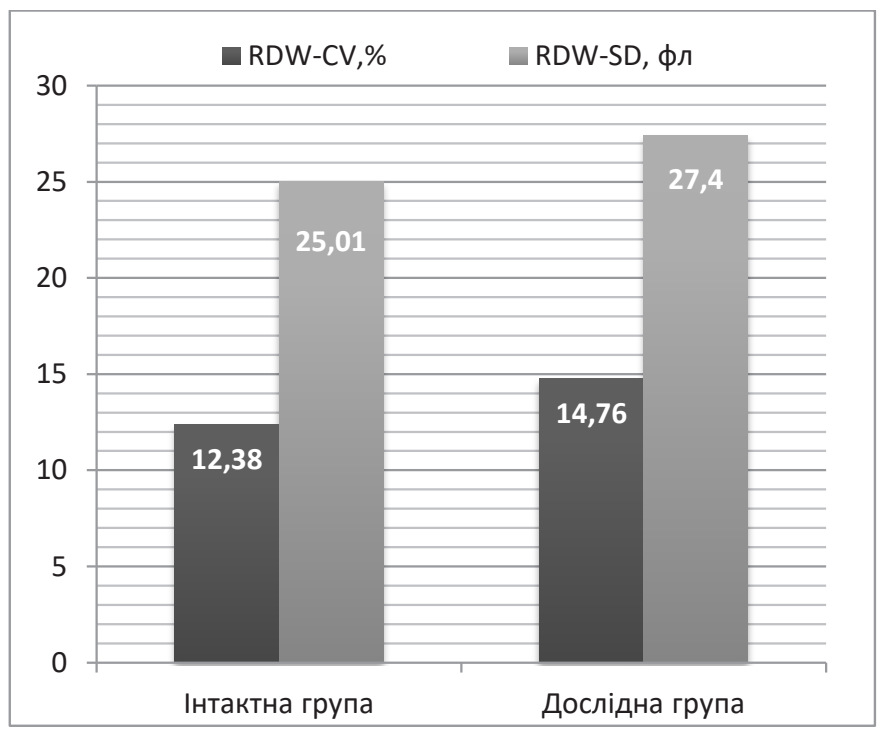

Рис. 2. Зміна гетерогенності еритроцитів на основі індексів анізоцитозу: коефіцієнта варіації (RDW-CV) та стандартного відхилення (RDW-SD).

Примітка. p<0,001, вірогідність відмінностей RDW-CV між контрольною і дослідними групами; p<0,20, вірогідність відмінностей RDW-SD між контрольною і дослідними групами.

Таблиця 2. Зміни клітин мегакаріоцитарної ланки, викликані циклофоссроамідом та G-CSF

\begin{tabular}{l|c|c|c}
\hline \multicolumn{1}{c|}{ Параметр } & $\mathrm{PLT}, 10^{9}$ & $\mathrm{PCT}$, л/л & $\mathrm{P}$-LCC, $10^{9} / л$ \\
\hline Інтактна група & $284,0 \pm 9,45$ & $21,75^{\star} 10^{-4} \pm 0,001$ & $45,0 \pm 1,54$ \\
\hline Дослідна група & $744,8 \pm 15,5$ & $57,75^{\star} 10^{-4} \pm 0,002$ & $94,2 \pm 1,82$ \\
\hline
\end{tabular}

Примітка. p<0,001, вірогідність відмінностей PLT, PCT, P-LCC між контрольною і дослідними групами.

рахунок активації тромбоцитів, що веде до утворення надмірної кількості фрракції великих тромбоцитів, та підтверджується достовірним ( $<<0,001)$ збільшенням у дослідній групі P-LCC на 52,23 \% порівняно з показниками інтактної групи тварин.
Відмічено незначне зменшення середнього об'єму тромбоцитів на 7,57 \%. Для виявлення або виключення анізотропії у клітинах мегакароцитарної ланки оцінено наступні параметри, а саме, PDW, MPV та P-LCR (рис. 3). Наростання гетерогенності популя- 


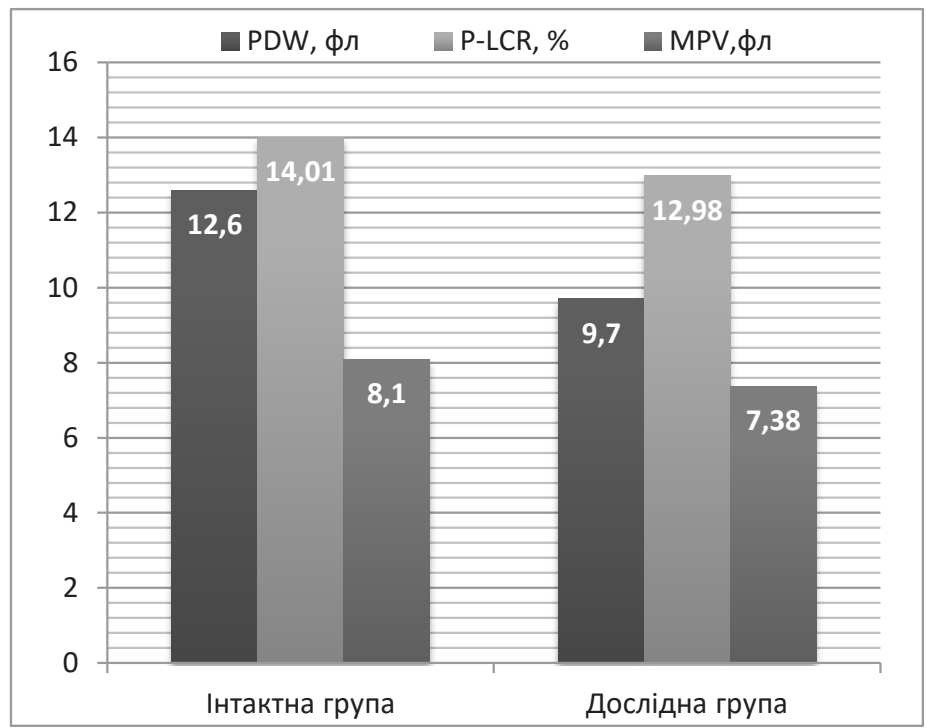

Рис. 3. Морфометричні характеристики гетерогенності та розміру популяції тромбоцитів (середній об'єм тромбоцита (МРV); ширина розподілу тромбоцита за об'ємом (PDW); відносний об'єм великих тромбоцитів (P-LCR)).

Примітка. p<0,001, вірогідність відмінностей MPV, P-LCR між контрольною і дослідними групами; р<0,01, вірогідність відмінностей PDW між контрольною і дослідними групами.

ції тромбоцитів оцінено на основі ширини розподілу тромбоцитів за об'ємом PDW. У дослідній групі даний параметр достовірно $(p<0,01)$ зменшився на 23,02 \%.

Ми діагностуємо активацію тромбоцитарного гемопоезу в дослідній групі тварин, на що вказує достовірне ( $<<0,001)$ збільшення P-LCC (табл. 2) на 52,23 \%. Як було встановлено в ході клінічних та експериментальних досліджень, великі за розмірами (P-LCC) тромбоцити мають вищу концентрацію рецепторів на поверхні. Такі клітини демонструють більш високі показники агрегації та були причиною тромбоутворення [10].
На основі аналізу лейкоцитарної формули ми констатуємо, що болюсна доза цитостатичного препарату, яка веде до імуносупресивного стану із тяжкими формами нейтропенії, була компенсована ін'єкціями гранулоцитарного колонієстимулювального фрактора впродовж трьох послідовних днів, про що свідчить збільшення у дослідній групі тварин загального числа лейкоцитів у 5 разів порівняно $з$ показниками інтактної групи тварин (рис. 4). У дослідній групі тварин на 21 добу експеременту ми виявили нейтрофрільний лейкоцитоз, на що вказує збільшення числа NEU у 14,5 раза, який зумовлений

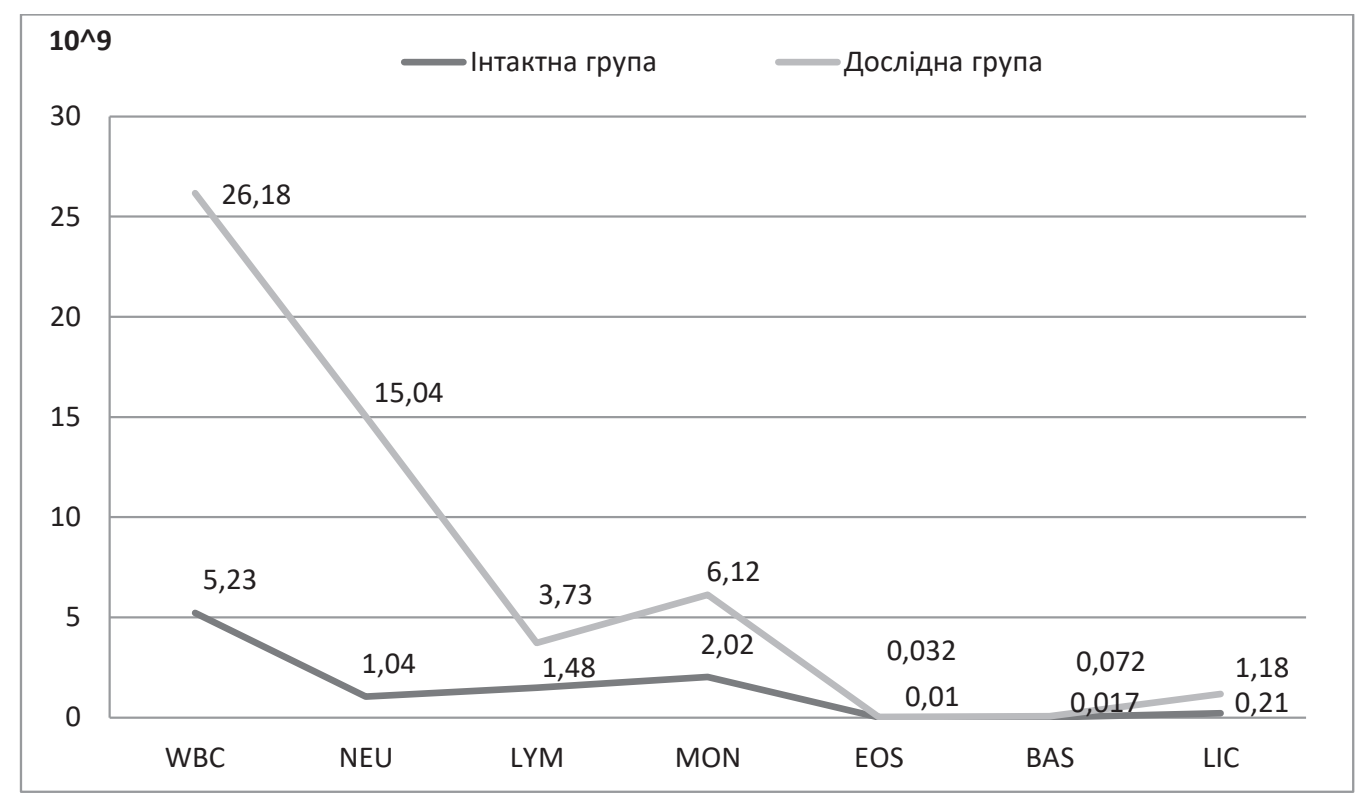

Рис. 4. Вплив циклофосфроаміду та G-CSF на клітиний імунітет мишей Balb/c. 
мобілізацією гемопоетичних стовбурових та прогеніторних клітин у периферійні органи кровотворення. Серед мієлоїдних клітин лейкоцитарного ряду спостерігається збільшення LYM, MON, EOS, BAS та LIC на 60,$32 ; 66,99 ; 68,75 ; 76,39$ та 82,2 \% відповідно.

\section{ВИСНОВКИ}

На основі змін гематологічних індексів перифрерійної крові ми виявили посилення гематопоезу клітин мієлоїдної та мегакаріацитарної ланки із компенсацією гематосупресії, викликаної циклофросороамідом. У віддалений період експерименту

\section{СПИСОК ЛІТЕРАТУРИ}

1. A novel variant on chromosome $7 q 22.3$ associated with mean platelet volume, counts, and function I N. Soranzo, A. Rendon3, C. Gieger [et al.] // Blood. 2009. Vol. 113 (16). - P. 3831-3837.

2. Association of mean platelet volume with risk of venous thromboembolism and mortality in patients with cancer. Results from the Vienna Cancer and Thrombosis Study (CATS) / J. Riedl, A. Kaider, EM. Reitter [et al.] // Thromb. Haemost. 2014. -Vol. 111 (4). - P. 670-678.

3. Consolini D. M. Thrombocytopenia in Infants and Children / D. M. Consolini // Pediatrics in Review. 2011. Vol. 32 (4). - P. 135-151.

4. Mobilization by either cyclophosphamide or granulocyte colony-stimulating factor transforms the bone marrow into a highly proteolytic environment / J. P. Levesque, J. Hendy, Y. Takamatsu [et al.] // Exp. Hematol. - 2002. - Vol. 30 (5). - P. 440-449.

5. High-dose cyclophosphamide as salvage therapy for severe aplastic anemia. / R. A. Brodsky, A. R. Chen, I. Brodsky [et al.] // Exp. Hematol. - 2004. - Vol. 32 (5). P. 435-440.

6. Increased mean platelet volume and immature platelet fraction as potential predictors of thrombotic complications in BCR/ABL-negative myeloproliferative neoplasms / J. Kissova, A. Bulikova, P. Ovesna [et al.] // Int. J. Hematol. - 2014. - Vol. 100 (5). - P. 429-436.

\section{REFERENCES}

1. Soranzo N, Rendon3 A, Gieger C. A novel variant on chromosome $7 q 22.3$ associated with mean platelet volume, counts, and function. Blood. 2009;113(16): 3831-7.

2. Riedl J, Kaider A, Reitter EM. Association of mean platelet volume with risk of venous thromboembolism and mortality in patients with cancer. Results from the Vienna Cancer and Thrombosis Study (CATS). Thromb Haemost. 2014;111(4): 670-8.

3. Consolini DM. Thrombocytopenia in infants and children. Pediatrics in Review. 2011;32(4): 135-51.

4. Levesque JP, Hendy J, Takamatsu Y, Williams B. Mobilization by either cyclophosphamide or granulocyte colony-stimulating factor transforms the bone marrow into a highly proteolytic environment. Exp Hematol. 2002;30(5): 440-9.

5. Brodsky RA, Chen AR, Brodsky I. High-dose в тварин дослідної групи діагностоване посилення еритропоезу з абсолютною компенсацією анемічних проявів, спричинених дією цитостатика, та із збереженням моророметричних показників у межах норми в нових популяціях еритроцитів. Діагностовано активацію тромбоцитарного гемопоезу в дослідній групі тварин, на що вказує достовірне збільшення таких показників, як RLT, PCT, P-LCC та P-LCR. Оцінка лейкоцитарної фрормули свідчить, що імуносупресія, викликана дією циклофосфоаміду, повністю компенсована ін'єкціями G-CSF, що підтверджено збільшенням NEU у 14,5 раза.

7. Mean platelet volume as a biomarker for thyroid carcinoma / Z. Bayhan, S. Zeren, I. Ozbay [et al.] // Int. Surg. - 2016. - Vol. 101 (1-2). - P. 50-53.

8. Mean platelet volume could be a possible biomarker for papillary thyroid carcinomas / S. Baldane, S. H. Ipekci, M. Sozen, L. Kebapcilar // Asian. Pac. J. Cancer. Prev. -2015. -Vol. 16 (7). - P. 2671-2674.

9. Platelet size for distinguishing between inherited thrombocytopenias and immune thrombocytopenia: a multicentric, real life study / P. Noris, C. Klersy, P. Gresele [et al.] // Br. J. Haematol. - 2013. - Vol. 162 (1). - P. 112-119.

10. Platelet volume indices in patients with coronary artery disease and acute myocardial infarction: an Indian scenario / M. M. Khandekar, A. S. Khurana, S. D. Deshmukh [et al.] // Journal of Clinical Pathology. - 2006. - No. 59. - P. 146-149.

11. Role of the spleen in cyclophosphamide-induced hematosuppression and extramedullary hematopoiesis in mice / Yuli Wang, Qinggang Meng, Haiquan Qiao [et al.] // Archives of Medical Research. - 2009. - Vol. 40 (4). - P. 249-255.

12. Вплив ендоксану на імунну систему щурів / Р. Ф. Амінов, О. К. Фролов, А. С. Амінова [та ін.] // Вісник Запорізького національного університету. Біологічні науки. - 2019. - № 1. - С. 5-13.

13. Полохов Д. М. Современные подходы в лабораторной диагностике тромбоцитарного гемостаза / Д. М. Полохов, М. А. Пантелеев // Гематология. Трансфузіологія. Восточная Европа. - 2016. - Т. 2, № 2. - С. 271- 290.

cyclophosphamide as salvage therapy for severe aplastic anemia. Exp Hematol. 2004;32(5): 435-40.

6. Kissova J., Bulikova A., Ovesna P. Increased mean platelet volume and immature platelet fraction as potential predictors of thrombotic complications in BCR/ABL-negative myeloproliferative neoplasms. Int J Hematol. 2014;100(5): 429-36.

7. Bayhan Z, Zeren S, Ozbay I. Mean platelet volume as a biomarker for thyroid carcinoma. Int Surg. 2016;101(12): $50-3$.

8. Baldane S, Ipekci SH, Sozen M, Kebapcilar L. Mean platelet volume could be a possible biomarker for papillary thyroid carcinomas. Asian Pac J Cancer Prev. 2015;16(7): 2671-4.

9. P. Noris, Klersy C, Gresele P. Platelet size for distinguishing between inherited thrombocytopenias and 
immune thrombocytopenia: a multicentric, real life study. $\mathrm{Br}$ J Haematol. 2013;162(1): 112-9.

10. Khandekar MM, Khurana AS, Deshmukh SD. Platelet volume indices in patients with coronary artery disease and acute myocardial infarction: an Indian scenario. Journal of Clinical Pathology. 2006;59: 146-9.

11. Yuli Wang, Qinggang Meng, Haiquan Qiao, Hongchi Jiang, Xueying Sun. Role of the Spleen in Cyclophosphamide-induced Hematosuppression and
Extramedullary Hematopoiesis in Mice. Archives of Medical Research. 2009;40(4): 249-55.

12. Aminov RF, Frolov AK, Aminova AS, Grankina AA, Sviridenko AP. [Effect of endoxane on the immune system of rats]. Visnyk Zaporizkoho natsionalnoho universytetu. Biolohichni nauky. 2019;1: 5-13. Ukrainian.

13. Polokhov D, Panteleev M. [Modern approaches in the laboratory diagnostics of platelet-dependent hemostasis]. Gematologiya. Transfuziologiya. Vostochnaya Yevropa. 2016;2(2) : 271-90. Russian

Отримано 09.10.20 